\title{
食物の色彩が視覚的な感性評価に与える影響
}

\author{
○岩佐和典 \\ (就実大学) \\ Key words: color, food, visual sensory evaluation
}

目的

色彩が感情や行動に与える影響については，すでに様々な 知見が蓄積されているが, 食物の色彩が食に関する視覚的な 感性評価に与える影響については, 未だ十分に明らかでない。 本研究では, 色相を操作した食物の画像を刺激として, 特に 見た目の「食べたさ」と色彩との関係を検討するとともに, 「食べたさ」に影響する心理的要因について検討する。

\section{方 法}

実験参加者：中国地方の大学生女子 55 名（18～23 歳, 平均年齢 20.25 歳, $S D=1.83$ )

口刺激画像：屋内の自然光下で撮影した食物の写真を加工 し，刺激画像を作成した。その際，実験刺激として採用した のは, うどん, 食パン, 干したスルメイカ, ポテトチップ, プリンの 5 種類だった。撮影後, 各画像の色彩を HSV 色空間 上で操作した。具体的には，彩度と明度を $50 \%$ に指定し，赤 を 0 度とした色相環上で， 60 度ごとに色相を指定した。その 結果, 赤, 黄色, 緑, 水色, 青, 紫にそれぞれ近似する 6 色 の画像が得られた。ここに自然色の画像を加え, 食物 1 種に つき 7 枚, 合計 35 枚の刺激画像が作成された。なお, 画像の 背景はすべて黒に統一した。

口評価項目： 35 枚の刺激画像について，以下 9 項目への回 答を 7 件法で求めた。(1)食べたさ, (2)色の自然さ, (3)嫌悪感 (気持ち悪さ), (4)腐敗の印象, (5)味覚イメージ：甘み, 旨味, 塩味, 苦味, 酸味。

実験器具： PC (EPSON 製) が 20 台設置された実験室を 用いて，各実験参加者に 1 台ずつ PC を割り当てて実験を実 施した。実験には表示色をキャリブレーションした 17 型スク エアの液晶モニターを用いた。刺激呈示の制御には M icrosoft PowerPoint 2010 を使用した。刺激画像の背景は黒に統一し, 刺激画像はモニター中央に 1 枚ずつ呈示した。画像のサイズ は $512 \times 400$ pixel とした。評価項目への回答は，すべて評価 用紙にボールペンで行うよう教示した。

口手続き： まず各実験参加者に，実験用のファイルが保存 された SD カードを 1 枚ずつ手渡し，自身に割り当てられた $P C$ で当該のファイルを実行するよう求めた。その後, 実験目 的と倫理的配慮について説明し，実験に同意した者にのみ実 験を実施した。実験に際しては，モニターに表示される画像 について，手元の評価用紙を用いて，印象を評定するよう求 めた。その際，画像は 1 枚ずつ別々に呈示された。そして，1 枚の画像に対する評定が終わり次第, キーボードのエンター キ一を押して次の画像に進むよう教示した。画像の呈示順は 乱数によってランダム化されており, 実験参加者ひとりひと りに異なる呈示順の実験ファイルが手渡された。なお，本実 験は就実大学研究倫理安全委員会から承認を得て実施された。

\section{結 果}

食物の色彩による「食べたさ」の違い：食物を視知覚し た際に，対象物の色彩が食べたさに対してどのような影響を 及ぼすか検討すべく，食物の色彩を独立変数，食べたさの評 定を従属変数とした, 1 要因 7 水準 (自然色, 赤, 黄色, 緑, 水色, 青, 紫) の反復測定分散分析を行った（図 1)。その際,
食物の種類による違いは考慮せず，すべて単一のデータセッ トにまとめて分析した。分析の結果, 食物の色彩による効果 が有意だった $(F(6,1644)=679.80, p<.000)$ 。多重比較の結 果, 自然色はその他の色彩に比べて有意に食べたさの評定值 が高かった（すべて $p<.000, d>2.00$ )。そして, 赤と黄色は, 紫, 緑, 水色, 青, 緑よりも有意に食べたさの評定值が高か った（すべて $p<.000, d=.51-1.11$ )。また, 紫は, 水色, 青, 緑よりも食べたさの評定値が高かった（すべて $p<.000, d$ $=.42-.58)$ 。以上, 反復測定分散分析の結果からは, 自然色 が最も食べたいと感じさせ, 以降は赤·黄色>紫>水色·青 · 緑の順に，食べたさが減じていくことが示された。

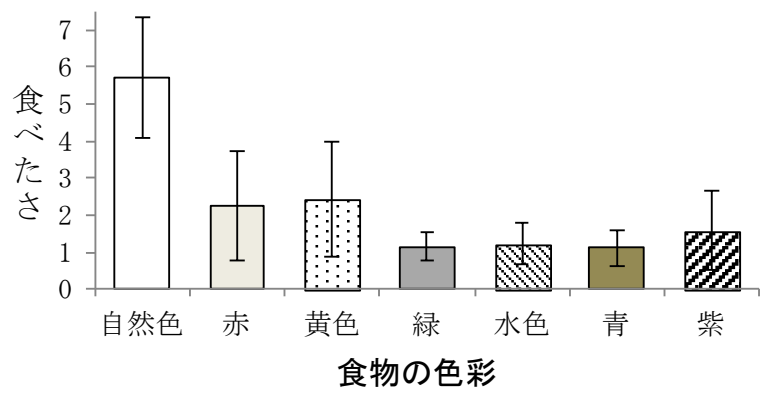

図 1 食物の色彩による食べたさの違い

食べたさに影響する心理的要因の検討： 様々な色彩の食 物を視知覚した際の「食べたさ」が, どのような心理的要因 に影響されるかを検討するために, 食べたさを目的変数, 色 の自然さ, 嫌悪感, 腐敗の印象, 味覚イメージ (甘み, 旨味, 塩味, 苦味, 酸味) を説明変数とした重回帰分析（ステップ ワイズ変数選択法) を行った。その結果, 自然さ $(2=.463, p$ <.000） と旨味 $(2=.257, p<.000)$ が有意な正の影響を及ぼ し, 嫌悪感 $(2=-.179, p<.000)$ が負の影響を及ぼしていたこ とが分かった。以上, 重回帰分析の結果からは, 自然さの感 覚が最も強く食べたさに影響することが示された。

考 察

自然色の画像が最も食べたいと評定されたこと，食べたさ の評定に最も強く影響する要因が自然さの印象だったことか ら，対象物の自然色との不一致から生じたであろう不自然さ の感覚が，食物を視知覚した際の食べたさを減じさせたもの と考えられる。今後は, 自然さの感覚を左右する刺激の特性 について検討し, 食物の色彩が視覚的な感性評価に及ぼす影 響のメカニズムを明らかにしていくことが求められる。

これに関連して, HSV 色相環上で, 赤とそれに隣接する黄 色，紫が比較的食べたさの評定が高く，水色とそれに隣接す る青と緑はそれが低いことが分かった。刺激画像が，おおむ ね自然色が黄色周辺に位置するものばかりだったことを考え ると, HSV 色相環上で自然色との距離が大きくなるほど, 食 べたさの評定值が低下する可能性を指摘できる。今後この点 を検証する実験を行うことが有益だと考えられる。

(Kazunor i IWASA) 